\title{
Article \\ Growth of Tea Nursery Plants as Influenced by Different Rates of Protein Hydrolysate Derived from Chicken Feathers
}

\author{
Sriharan Raguraj ${ }^{1,2}$, Susilawati $\operatorname{Kasim}^{1, *}$, Noraini Md Jaafar ${ }^{1}$ (D) and Muhamad Hazim Nazli ${ }^{3}$ (D) \\ 1 Department of Land Management, Faculty of Agriculture, Universiti Putra Malaysia, \\ Serdang 43400, Malaysia; raguraj90@yahoo.com (S.R.); j_noraini@upm.edu.my (N.M.J.) \\ 2 Soils and Plant Nutrition Division, Tea Research Institute of Sri Lanka, Talawakelle 22100, Sri Lanka \\ 3 Department of Crop Science, Faculty of Agriculture, Universiti Putra Malaysia, Serdang 43400, Malaysia; \\ m_hazim@upm.edu.my \\ * Correspondence: susilawati@upm.edu.my
}

Citation: Raguraj, S.; Kasim, S.; Md Jaafar, N.; Nazli, M.H. Growth of Tea Nursery Plants as Influenced by Different Rates of Protein Hydrolysate Derived from Chicken Feathers. Agronomy 2022, 12, 299. https://doi.org/10.3390/ agronomy12020299

Academic Editor: Valentina Scariot

Received: 4 December 2021

Accepted: 20 December 2021

Published: 25 January 2022

Publisher's Note: MDPI stays neutral with regard to jurisdictional claims in published maps and institutional affiliations.

Copyright: (C) 2022 by the authors. Licensee MDPI, Basel, Switzerland. This article is an open access article distributed under the terms and conditions of the Creative Commons Attribution (CC BY) license (https:// creativecommons.org/licenses/by/ $4.0 /)$.

\begin{abstract}
The conversion of chicken feathers, generated annually worldwide on a large scale as a by-product of the poultry industry into value-added products, has economic and environmental benefits. Protein hydrolysate produced from feathers has attracted significant attention in agriculture as a potential plant growth stimulant. Therefore, a study was established with the aim to produce and characterize chicken feather protein hydrolysate (CFPH) and investigate the effects of this product on the early growth of nursery tea plants. Alkaline hydrolysis was used to produce CFPH with the yield of $165 \mathrm{mg}$ amino acids per gram of feathers. Then, the produced CFPH was applied on nursery tea plants as a soil drench at different doses $\left(0.5,1,2,3\right.$, and $\left.4 \mathrm{~g} \mathrm{~L}^{-1}\right)$ in 2-week intervals until the 10th application. Commercially available fish protein hydrolysate (FPH) was included as a treatment to compare the effects with CFPH. The treatments were arranged in a completely randomized block design with three replications. CFPH and FPH significantly improved the shoot and root growth parameters. Plant height $(+98 \%)$, leaf number $(+61 \%)$, shoot dry biomass $(+128 \%)$, root length $(+94 \%)$, root surface area $(+15 \%)$, and root dry biomass $(+152 \%)$ were significantly increased by the application of CFPH ( $2 \mathrm{~g} \mathrm{~L}^{-1}$ dose) compared to control. Although the highest CFPH dosage $\left(4 \mathrm{~g} \mathrm{~L}^{-1}\right)$ showed a reduction in growth parameters, the values obtained were similar or higher than the untreated control plants. The chlorophyll content ( $a, b$, and total) was enhanced by the CFPH dosage of $1 \mathrm{~g} \mathrm{~L}^{-1}$, whereas the highest photosynthetic rate was recorded in the CFPH $3 \mathrm{~g} \mathrm{~L}^{-1}$ treatment. The application of protein hydrolysates $(\mathrm{PH})$ did not positively influence stomatal conductance and intercellular $\mathrm{CO}_{2}$ concentration. Leaf nitrogen, phosphorous, manganese, and copper were positively affected by the CFPH application. The effect of CFPH on growth parameters was more pronounced than FPH. Our findings reveal that CFPH produced by alkaline hydrolysis could be used as a growth booster in raising vigorous tea nursery plants, which are most suitable for field planting and subsequently higher yields.
\end{abstract}

Keywords: chicken feather; alkaline hydrolysis; protein hydrolysate; growth promoter; tea nursery plants

\section{Introduction}

In recent years, the production of poultry meat has snowballed to cater to the growing demand. Poultry meat production reached 112.9 million metric tons in 2018, contributing $33 \%$ of the world meat production [1]. Feathers comprise $5-7 \%$ of the total live body weight of a mature chicken [2] and every week, nearly 3000 tons of feather waste is generated globally [3]. Feather waste consists of bloodstains and may have a considerably large load of viruses and other pathogenic microorganisms [4]. In addition, their improper disposal causes severe damage to the environment and human health.

Feathers are made up of over 91\% keratin, a structural and fibrous protein with a high degree of cross-linking of peptide chain by forming disulphide bonds [4]. Keratin is highly insoluble, mechanically stable, and resistant to degradation by most proteolytic 
enzymes [5]. Since the natural degradation of feathers takes more than 2 years [6], leftover feathers are disposed of through landfilling or burning. Nevertheless, these methods are not eco-friendly. Feathers are utilized to produce feather meal, a potential animal feed. However, avian disease outbreaks and potential risks of disease transmissions limited the recycling process [7]. Feather waste is rich in nitrogen that is up to $15 \%$ of its total weight and is a good protein and amino acids source. The production of protein hydrolysates (PH) from agro-industrial by-products is a sustainable remedy for waste disposal and for the addition of economic value [8]. In the recent past, the isolation of $\mathrm{PH}$ from the by-products in slaughterhouses has been re-used due to their functional and bioactive properties [5].

PH are produced from both plant and animal protein sources using partial hydrolysis [9], which consists of a mixture of peptides, oligopeptides, and amino acids. However, they may have carbohydrates, small quantities of mineral elements, phenols, and other compounds [10] that have shown promising influence on plant growth performances [11]. $\mathrm{PH}$ are used in broad areas, including medicine, nutrition, food, and agriculture, due to their nutritional and functional/bioactive properties [12]. These are available in the markets as liquid extracts or soluble powder and granule forms and can be applied as root or foliar applications [11]. Many studies have reported that $\mathrm{PH}$ with low molecular weight peptides and free amino acids showed more pronounced effects due to the easy absorption by all plant tissues $[13,14]$. In addition, a significant growth promotion was observed when it is applied at low rates irrespective of the type of crop [15-17]. PH directly influence the plant by stimulation of carbon and nitrogen metabolism, regulation of nitrogen assimilation $[18,19]$, and interference with hormonal activities through bioactive peptides [11,20]. In addition, they indirectly affect growth and plant nutrition [18]. The foliar and root application of PH increases the nutrient uptake and nutrient use efficiency $[11,21,22]$. Enhanced nutrient uptake links with root architecture modification result in more available micronutrients, due to complexation and chelation as well as higher microbial activity [23].

Compared to vegetal-derived $\mathrm{PH}$, animal-derived $\mathrm{PH}$ have higher nitrogen content (9-16\%) and are released gradually [24]. Furthermore, the use of animal-derived PH as a biostimulant in agriculture is a cost-effective approach, since most of the raw materials used are collected from wastes. Animal-derived PH have been employed for more than 50 years due to their capacity to stimulate plant growth and ameliorate the effects of environmental stresses [25]. Despite the positive effects on plants, studies have reported adverse effects of commercial PH derived from animal sources, which mainly cause phytotoxicity and plant growth retardation when applied as foliar [14,26,27]. This negative impact on growth is associated with a higher concentration of free amino acids [28] and salts [20] in the products. In addition, there is a limitation on the usage of animal-derived PH on food safety due to the ban on its use on edible parts of crops under organic farming (European Regulation no. 354/2014). Nevertheless, the evaluation of safety and fertilizer efficacy revealed that it could be applied in conventional and organic farming with no potential risk to the human health and the ecosystem [29].

The application of $\mathrm{PH}$ for a short period increased the root dry weight of maize plants compared to the untreated plants [21]. Furthermore, Nardi et al. [30] reported that exerted short-term effects on root growth were consistent and comparable with humic substances, and finally resulted in enhanced shoot growth over long periods. Moreover, an increase in root dry weight might result in a greater survival rate of transplanted plants, which leads to higher yields. Furthermore, the application of chicken feather protein hydrolysate (CFPH) enhanced the germination and secondary root development of Bengal gram seedlings [31]. In another study, wheat seedlings treated with CFPH increased root and shoot lengths, fresh and dry mass, and the photosynthetic pigment content [32]. Although the beneficial effects of CFPH on the early growth of annual crops has been reported, the information available on the early growth of woody perennials is limited. Tea [Camellia sinensis (L.) O. Kuntze] is a woody perennial commercial crop widely cultivated in tropical and subtropical regions of the world. The proper management of tea plants in the nursery stage is the first and foremost step in successful tea cultivation in the field. The growth performance of tea 
nursery plants in response to CFPH has not been explored. Therefore, this study aimed to produce and characterize the CFPH and identify the optimum rate that would exert the biostimulant action on the early growth of tea nursery plants.

\section{Materials and Methods}

\subsection{Preparation of Chicken Feather}

Chicken feathers were collected from a broiler farm located in Selangor, Malaysia. The collected feathers were thoroughly washed with tap water to remove blood and other foreign materials. Feathers were re-washed with distilled water and oven-dried at $75{ }^{\circ} \mathrm{C}$ for 3 days. Oven-dried samples were cut into small pieces and ground until they turned into thin feather wool.

\subsection{Production of Chicken Feather Protein Hydrolysate}

The hydrolysis of chicken feathers was carried out with a modification of a method used by Taskin et al. [33] and Genç and Atici [32]. Briefly, $5 \mathrm{~g}$ of feather wool was weighed into a shaking bottle, and $100 \mathrm{~mL}$ of $2 \mathrm{~N} \mathrm{KOH}$ was added. A hydrolysis process was conducted by gentle shaking the mixture in an orbital shaker for 3 days. Then, the $\mathrm{pH}$ of the extract was adjusted to a $\mathrm{pH}$ of 7 using $10 \mathrm{~N} \mathrm{H}_{3} \mathrm{PO}_{4}$ and it was filtered using Whatman filter paper to remove the non-hydrolysable particles. The filtrate was collected and oven-dried at $70{ }^{\circ} \mathrm{C}$ until a constant weight was obtained. This oven dried sample was referred to as $\mathrm{CFPH}$.

\subsection{Analysis of Chicken Feather and CFPH}

Total carbon, nitrogen, and sulphur contents were determined using a TruMac CNS analyzer (LECO, Saint Joseph, MI, USA). Both the chicken feather and CFPH were digested using an acid digestion and the macro and micronutrients were determined by the inductively coupled plasma-optical emission spectrometry (ICP-OES) (Optima 8300, PerkinElmer, Waltham, MA, USA). Table 1 summarizes the nutrient composition of both the raw chicken feather and CFPH.

Table 1. Chemical composition of the raw chicken feather and CFPH.

\begin{tabular}{|c|c|c|}
\hline Elements & Chicken Feather & CFPH \\
\hline Total C (\%) & 47.09 & 9.42 \\
\hline Total N (\%) & 13.54 & 3.06 \\
\hline $\mathrm{C} / \mathrm{N}$ ratio & 2.81 & 2.31 \\
\hline $\mathrm{P}(\%)$ & 0.12 & 17.13 \\
\hline $\mathrm{K}(\%)$ & 0.29 & 25.41 \\
\hline $\mathrm{Ca}(\%)$ & 0.31 & 0.074 \\
\hline $\operatorname{Mg}(\%)$ & 0.03 & 0.007 \\
\hline $\mathrm{S}(\%)$ & 1.61 & 0.44 \\
\hline $\mathrm{Zn}\left(\mathrm{mg} \mathrm{kg}^{-1}\right)$ & 0.02 & $<0.01$ \\
\hline $\operatorname{Mn}\left(\mathrm{mg} \mathrm{kg}^{-1}\right)$ & $<0.01$ & $<0.01$ \\
\hline $\mathrm{Cu}\left(\mathrm{mg} \mathrm{kg}^{-1}\right)$ & $<0.01$ & $<0.01$ \\
\hline $\mathrm{Fe}\left(\mathrm{mg} \mathrm{kg}{ }^{-1}\right)$ & 0.04 & $<0.01$ \\
\hline
\end{tabular}

\subsection{Amino Acid Profile}

The amino acid composition of CFPH was determined by high-performance liquid chromatography (Waters Alliance e2695) with a fluorescence detector using the HPLC column (AccQ tag/3.9 $\times 150 \mathrm{~mm}$ ). The amino acid amount was determined by establishing an external standard calibration curve for individual amino acids.

\subsection{Plant Materials and Treatment Application}

This experiment was carried out at University Putra Malaysia located in Serdang, in a polyethylene greenhouse under $70 \%$ shading. Herein, 8-week-old uniform size healthy 
tea (Camellia sinensis) plants propagated by single-node cuttings were selected for this experiment. These plants were planted in poly bags containing a mixture of topsoil and sand (ratio 2:1). Each experimental unit consisted of five plants. The treatments were arranged in a complete randomized block design with three replicates with a total of 21 experimental units. The treatments were the control, different doses of CFPH $(0.5,1,2,3$, and $\left.4 \mathrm{~g} \mathrm{~L}^{-1}\right)$, and fish protein hydrolysate (FPH) at the recommended dosage $\left(10 \mathrm{~mL} \mathrm{~L}^{-1}\right)$, which was given by the manufacturer. The $\mathrm{pH}$ of the solution was adjusted to $4.5-5.5$ before the application in order to ensure an optimum $\mathrm{pH}$ for the growth of tea plants. The applied $\mathrm{PH}$ volume was $20 \mathrm{~mL}_{\text {plant }}{ }^{-1}$, and the control plants received the same amount of water. The PH were applied as a soil drench at 2-week intervals following the fertilization. The FPH was used as a positive control to compare the effects. Fertilization was conducted by dissolving the fertilizer mixture in water and applied at fortnight intervals alternatively to the $\mathrm{PH}$ application.

\subsection{Plant Growth Measurements}

Plant height was measured from the apical bud of the stem to the ground surface, and the number of leaves was counted. Plant fresh weight was measured immediately after harvesting, and the average dry weight was determined after an oven-dried condition at $70{ }^{\circ} \mathrm{C}$ for $72 \mathrm{~h}$.

\subsection{Root Growth Measurements}

Roots were carefully washed to remove soil, and the fresh root weight was taken. Roots were fully spread on a transparent tray and scanned at $400 \mathrm{dpi}$ with a scanner (Epson Perfection V700). Root positioning and scanning were conducted with Regent's positioning system. The images acquired by WinRHIZO were identified by colored lines and processed using an image analysis software (WinRHIZO Pro 2000, Regent Instruments Inc., Quebec City, QC, Canada).

\subsection{Leaf Gas Exchange}

The photosynthetic rate, stomatal conductance, intercellular $\mathrm{CO}_{2}$ concentration, and transpiration rate were measured using an infrared gas analyzer (Li-6400XT Portable Photosynthesis System, Li-Cor, Lincoln, NE, USA). The Li-6400XT is an open system, which measures photosynthesis and transpiration based on the differences in $\mathrm{CO}_{2}$ and $\mathrm{H}_{2} \mathrm{O}$ in the in-chamber and pre-chamber conditions. Measurements were taken from the tip of the fourth leaf. The chamber airflow and $\mathrm{CO}_{2}$ concentrations were $300 \mu \mathrm{mol} \mathrm{s}^{-1}$ and $400 \mathrm{ppm}$, respectively. Measurements were recorded at the same time of the day (09.00-11.00) to minimize the changes in the readings due to environmental factors.

\subsection{Chlorophyll Content}

Chlorophyll $a, b$, and total chlorophyll were determined based on the method described by Coombs et al. [34]. Briefly, four-leaf discs of $1 \mathrm{~cm}^{2}$ were taken from the fourth leaf using a cork borer. The samples were brought to the lab and kept in a vial together with $80 \%$ $(v / v)$ acetone in the dark for $48-60 \mathrm{~h}$ at room temperature. After the pigments were totally absorbed into the acetone solution, each sample was measured for absorbance at 647 and $664 \mathrm{~nm}$ using a UV-visible spectrophotometer (UV-1700 PharmaSpec, Shimadzu, Japan).

\subsection{Leaf Nutrient Analysis}

Leaf samples were oven-dried at $60{ }^{\circ} \mathrm{C}$ until a constant weight. Dried leaves were ground using a leaf grinder to a particle size of $1 \mathrm{~mm}$. The total nitrogen content of the leaf samples was determined by the Kjeldahl method [35], following acid digestion in sulphuric acid in the presence of a catalyst (Kjeldahl tablets). Regarding the other macro and micronutrient analyses, $0.2 \mathrm{~g}$ of finely ground leaf samples were subjected to drywashing in a muffle furnace at $550{ }^{\circ} \mathrm{C}$ for $8-10 \mathrm{~h}$. Thereafter, the ash was moistened with a few drops of distilled water, followed by $2 \mathrm{~mL}$ of con $\mathrm{HCl}$ and $10 \mathrm{~mL}$ of $20 \% \mathrm{HNO}_{3}$. The ash 
was dissolved by placing it in a water bath for $1 \mathrm{~h}$. The sample was filtered and transferred to a $50 \mathrm{~mL}$ volumetric flask and made to volume with deionized water. Phosphorous was determined by the vanadate yellow color method, using a UV-visible spectrophotometer (UV-1700 PharmaSpec) at $425 \mathrm{~nm}$ wavelength. Potassium, $\mathrm{Ca}, \mathrm{Mg}$, and micronutrients were measured using an atomic absorption spectrometer (Analyst 400, PerkinElmer, USA).

\subsection{Statistical Analysis}

All of the data were subjected to the one-way analysis of variance (ANOVA) using the statistical analysis system (SAS) 9.4 and expressed as mean values at \pm standard error. The least significant difference (LSD) at a 5\% confidence level was set to compare the treatment means.

\section{Results}

\subsection{Production and Characterization of CFPH}

The amino acid composition of the CFPH produced from alkaline hydrolysis of feathers is summarized in Table 2.

Table 2. Amino acid composition of chicken feather protein hydrolysate.

\begin{tabular}{|c|c|c|}
\hline Amino Acids & Amino Acids (\%) & Chicken Feather $\left(\mathrm{mg} \mathrm{g}^{-1}\right)$ \\
\hline Alanine & 6.21 & 10.27 \\
\hline Arginine & 6.61 & 10.94 \\
\hline Aspartic acid & 8.03 & 13.29 \\
\hline Cysteine & 0.79 & 1.30 \\
\hline Glutamic acid & 13.36 & 22.11 \\
\hline Glycine & 7.28 & 12.04 \\
\hline Histidine & ND & 0.00 \\
\hline Isoleucine & 6.28 & 10.40 \\
\hline Leucine & 9.42 & 15.59 \\
\hline Lysine & 2.73 & 4.53 \\
\hline Methionine & 0.75 & 1.25 \\
\hline Phenylalanine & 4.77 & 7.90 \\
\hline Proline & 11.75 & 19.45 \\
\hline Serine & 8.11 & 13.43 \\
\hline Threonine & 2.42 & 3.71 \\
\hline Tyrosine & 2.56 & 4.24 \\
\hline Valine & 9.06 & 14.99 \\
\hline Hydroxyproline & ND & 0.00 \\
\hline Total & 100 & 165.50 \\
\hline
\end{tabular}

ND: Not detected.

The production of chicken feather protein hydrolysate using chemical hydrolysis is a faster and simpler process with higher yields. The alkaline hydrolysis adopted in this study, without any heating treatment, yielded a higher concentration of amino acids $\left(165.5 \mathrm{mg} \mathrm{g}^{-1}\right.$ of feathers). Amino acid profiling revealed the presence of 16 amino acids in the CFPH including higher amounts of essential amino acids (valine, leucine, and isoleucine) and non-essential amino acids (serine and glycine). Both the glutamic acid and proline alone contribute $25 \%$ of the total amino acid composition. Minute quantities of cysteine and methionine were detected, while histidine and hydroxyproline were absent.

\subsection{Shoot Growth}

In this experiment, $\mathrm{PH}$ derived from $\mathrm{CFPH}$ and $\mathrm{FPH}$ showed a positive influence on plant height, leaf number, and shoot fresh and dry weights (Figure 1, Table 3). CFPH applied at the rate of $2 \mathrm{~g} \mathrm{~L}^{-1}$ significantly increased all of the shoot growth parameters compared to the FPH and control treatments. The response of tea plants treated with CFPH $1 \mathrm{~g} \mathrm{~L}^{-1}$ was comparable with the CFPH $2 \mathrm{~g} \mathrm{~L}^{-1}$ dosage, except for plant height. 


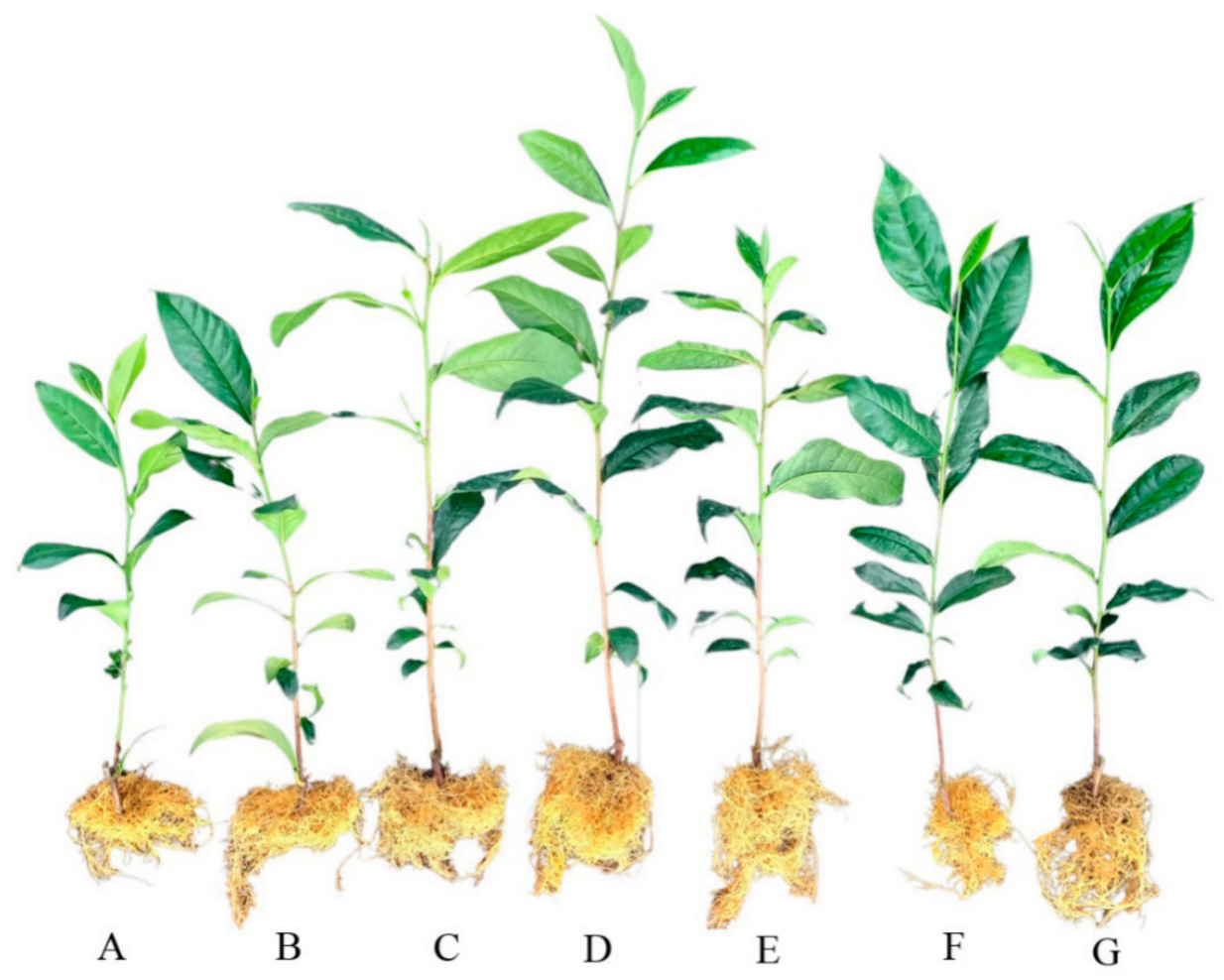

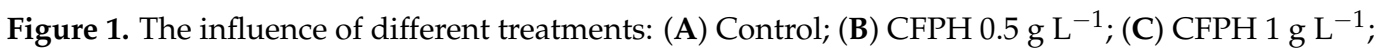
(D) CFPH $2 \mathrm{~g} \mathrm{~L}^{-1}$; (E) CFPH $3 \mathrm{~g} \mathrm{~L}^{-1}$; (F) CFPH $4 \mathrm{~g} \mathrm{~L}^{-1}$, and (G) FPH $10 \mathrm{~mL} \mathrm{~L}^{-1}$ on the growth of tea nursery plants.

Table 3. Effect of animal origin PH on plant height, leaf number, and shoot fresh and dry weights.

\begin{tabular}{|c|c|c|c|c|}
\hline Treatment & Plant Height $(\mathrm{cm})$ & Leaf Number (n plant ${ }^{-1}$ ) & $\begin{array}{l}\text { Shoot Fresh Weight } \\
\left(\text { g plant }^{-1}\right)\end{array}$ & $\begin{array}{l}\text { Shoot Dry Weight } \\
\left.\text { (g plant }^{-1}\right)\end{array}$ \\
\hline Control & $22.7 \pm 1.4^{\mathrm{e}}$ & $7.0 \pm 0.6^{\mathrm{d}}$ & $6.6 \pm 0.4^{\mathrm{e}}$ & $2.13 \pm 0.17^{\mathrm{e}}$ \\
\hline CFPH $0.5 \mathrm{~g} \mathrm{~L}^{-1}$ & $27.2 \pm 1.0^{\mathrm{d}}$ & $8.0 \pm 0.6^{\mathrm{cd}}$ & $8.5 \pm 0.5^{\mathrm{d}}$ & $2.76 \pm 0.23 \mathrm{de}$ \\
\hline CFPH $1 \mathrm{~g} \mathrm{~L}^{-1}$ & $39.6 \pm 0.7^{b}$ & $10.0 \pm 0.6^{\mathrm{ab}}$ & $12.5 \pm 0.6^{\mathrm{ab}}$ & $4.23 \pm 0.43^{\mathrm{ab}}$ \\
\hline CFPH $2 \mathrm{~g} \mathrm{~L}^{-1}$ & $45.0 \pm 1.1^{\mathrm{a}}$ & $11.3 \pm 0.3^{a}$ & $13.7 \pm 0.7^{\mathrm{a}}$ & $4.87 \pm 0.27^{\mathrm{a}}$ \\
\hline CFPH $3 \mathrm{~g} \mathrm{~L}^{-1}$ & $37.7 \pm 0.6^{b c}$ & $8.6 \pm 0.3^{b c}$ & $12.2 \pm 0.6^{\mathrm{abc}}$ & $4.03 \pm 0.32 \mathrm{bc}$ \\
\hline CFPH $4 \mathrm{~g} \mathrm{~L}^{-1}$ & $34.3 \pm 1.3^{c}$ & $8.6 \pm 0.3^{b c}$ & $10.6 \pm 0.5^{c}$ & $2.73 \pm 0.06$ de \\
\hline FPH $10 \mathrm{~mL} \mathrm{~L}^{-1}$ & $37.0 \pm 1.5 \mathrm{bc}$ & $8.6 \pm 0.3^{b c}$ & $11.5 \pm 0.5^{b c}$ & $3.31 \pm 0.13^{\mathrm{cd}}$ \\
\hline
\end{tabular}

The same letters within each column are not significantly different at the $p<0.05$ level.

Increasing the dosage of CFPH significantly enhanced the shoot growth parameters up to $2 \mathrm{~g} \mathrm{~L}^{-1}$, in which it showed growth inhibition. The highest CFPH dosage of $4 \mathrm{~g} \mathrm{~L}^{-1}$ improved all of the shoot growth parameters, except for the shoot dry biomass compared to the control plants. All of the applied doses of CFPH increased the plant height and shoot fresh weight. Tea plants positively responded to the FPH application and the exerted effects were comparable with 1 and $3 \mathrm{~g} \mathrm{~L}^{-1} \mathrm{CFPH}$ dosages.

\subsection{Root Growth}

A well-developed root system is considered an essential requirement for the successful field planting of tea. The applied animal-based protein hydrolysates positively influenced the root growth parameters of tea nursery plants (Figure 2). 
A

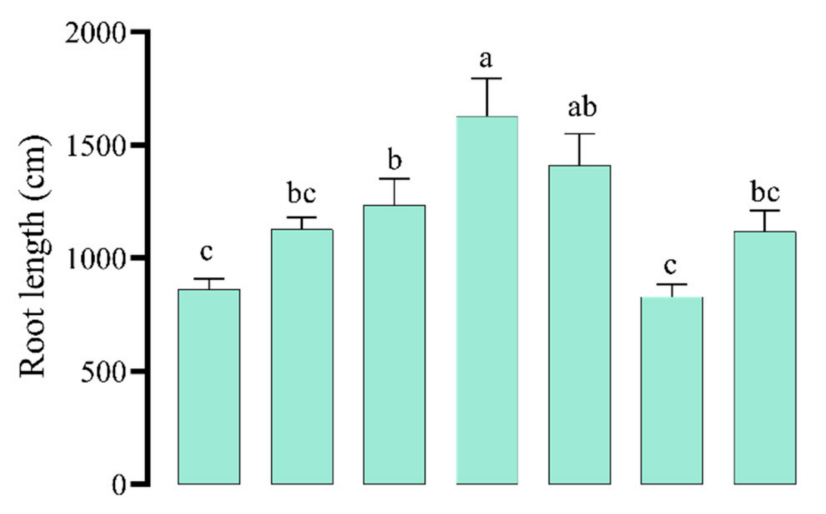

B

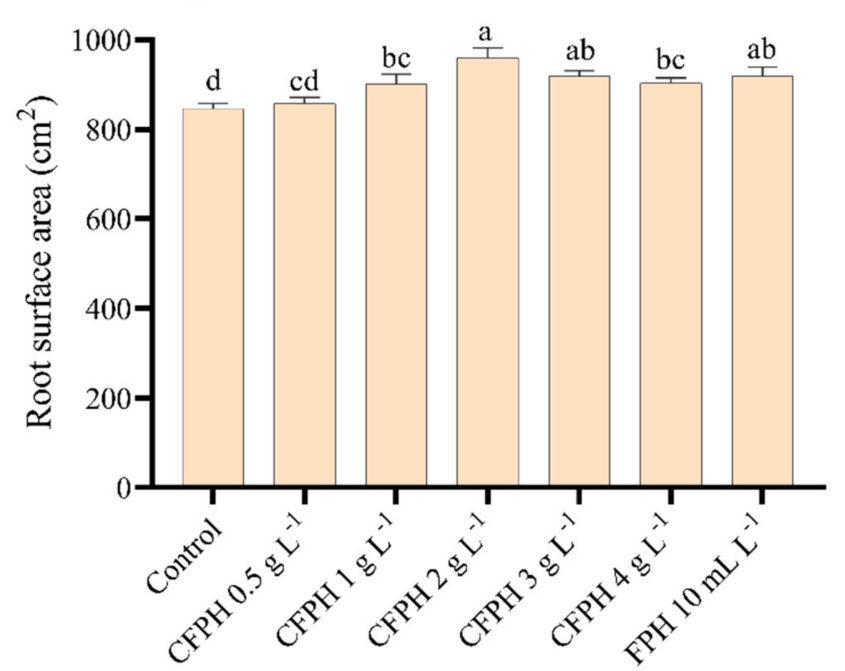

C

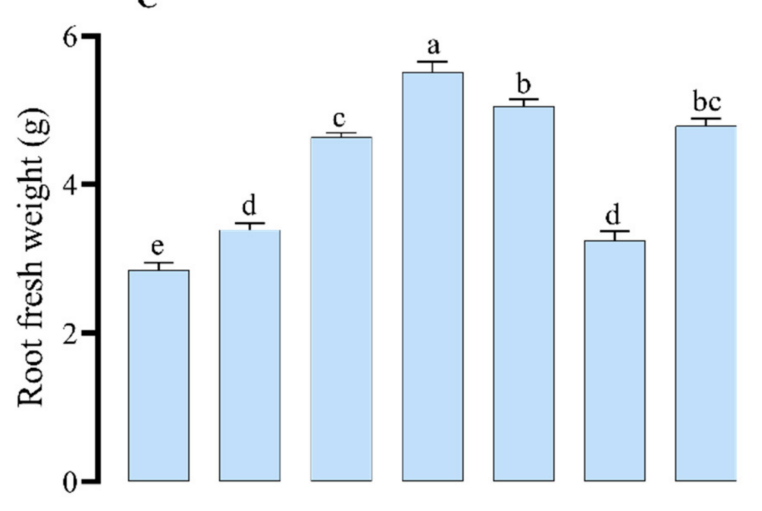

D

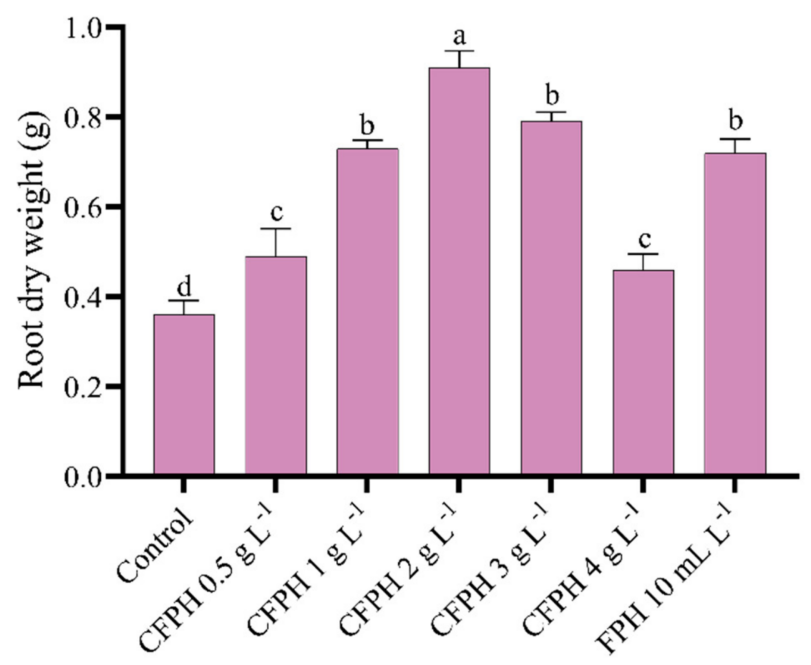

Figure 2. Effect of animal origin PH on root length (A), root surface area (B), root fresh weight (C), and root dry weight (D). The small bar shows the standard error. The columns with the same letters are not significantly different at the $p<0.05$ level.

Soil drenching of CFPH had positive effects on root length, surface area, as well as root fresh and dry weights, especially when applied at the rate of $2 \mathrm{~g} \mathrm{~L}^{-1}$ compared to the control plants. The influence of CFPH $3 \mathrm{~g} \mathrm{~L}^{-1}$ dosage on root length and surface area were comparable with CFPH $2 \mathrm{~g} \mathrm{~L}^{-1}$, whereas root fresh and dry weights were significantly lower. No differences were found for root length, surface area, and root dry weight between 1 and $3 \mathrm{~g} \mathrm{~L}^{-1}$ doses of CFPH treatments. The plants treated with the lowest $\left(0.5 \mathrm{~g} \mathrm{~L}^{-1}\right)$ and highest $\left(4 \mathrm{~g} \mathrm{~L}^{-1}\right)$ doses of CFPH showed a similar response on all the root growth parameters. The increasing concentration of $\mathrm{CFPH}$ showed a similar trend observed in shoot growth, where maximum values were observed at the $2 \mathrm{~g} \mathrm{~L}^{-1}$ dosage. The positive action of FPH on root growth was observed and the exerted effects were comparable with both the 1 and $3 \mathrm{~g} \mathrm{~L}^{-1}$ rates of $\mathrm{CFPH}$.

\subsection{Chlorophyll Content}

The application of PH significantly increased the leaf chlorophyll $a$, chlorophyll $b$, and total chlorophyll contents (Figure 3). The highest values were recorded in the $\mathrm{CFPH}$ $1 \mathrm{~g} \mathrm{~L}^{-1}$ treatment. There were no significant differences observed between the 1 and $3 \mathrm{~g} \mathrm{~L}^{-1}$ dosages. Although both animal origin PH improved the leaf chlorophyll content, the positive effects of $\mathrm{CFPH}$ were more pronounced than $\mathrm{FPH}$. 




Figure 3. Effect of animal origin PH on leaf chlorophyll $a$, chlorophyll $b$, and total chlorophyll contents. The small bar shows the standard error. The columns with the same letters are not significantly different at the $p<0.05$ level.

\subsection{Leaf Gas Exchange}

Table 4 shows the influence of PH application on leaf gas exchange. The photosynthetic and transpiration rates were enhanced by 9.65 and $26.5 \%$, respectively with the CFPH $3 \mathrm{~g} \mathrm{~L}^{-1}$ treatment compared to the control. Both the CFPH and FPH positively enhanced the photosynthetic rate of nursery plants. However, the transpiration rate was significantly higher in the CFPH $3 \mathrm{~g} \mathrm{~L}^{-1}$ treatment than FPH.

Table 4. Effects of animal origin $\mathrm{PH}$ on leaf gas exchange.

\begin{tabular}{ccccc}
\hline Treatment & Pn & Gs & Ci & Tr \\
\hline Control & $10.88 \pm 0.21^{\mathrm{b}}$ & $0.22 \pm 0.02^{\mathrm{a}}$ & $290 \pm 12^{\mathrm{a}}$ & $6.17 \pm 0.36^{\mathrm{bc}}$ \\
CFPH 0.5 g L & $11.15 \pm 0.20^{\mathrm{ab}}$ & $0.26 \pm 0.01^{\mathrm{a}}$ & $292 \pm 10^{\mathrm{a}}$ & $6.99 \pm 0.13^{\mathrm{ab}}$ \\
CFPH 1 g L $^{-1}$ & $10.59 \pm 0.20^{\mathrm{b}}$ & $0.21 \pm 0.03^{\mathrm{a}}$ & $283 \pm 07^{\mathrm{a}}$ & $5.78 \pm 0.09^{\mathrm{c}}$ \\
${\text { CFPH 2 } \text { L }^{-1}}^{\mathrm{a}}$ & $10.47 \pm 0.26^{\mathrm{b}}$ & $0.23 \pm 0.04^{\mathrm{a}}$ & $289 \pm 04^{\mathrm{a}}$ & $6.54 \pm 0.46^{\mathrm{bc}}$ \\
CFPH 3 g L $^{\mathrm{a}}$ & $11.93 \pm 0.42^{\mathrm{a}}$ & $0.25 \pm 0.02^{\mathrm{a}}$ & $287 \pm 03^{\mathrm{a}}$ & $7.81 \pm 0.18^{\mathrm{a}}$ \\
${\text { CFPH } 4 \text { g L}^{-1}}^{\mathrm{a}}$ & $10.65 \pm 0.24^{\mathrm{b}}$ & $0.26 \pm 0.01^{\mathrm{a}}$ & $295 \pm 07^{\mathrm{a}}$ & $7.03 \pm 0.44^{\mathrm{ab}}$ \\
FPH 10 mL L & $11.20 \pm 0.35^{\mathrm{ab}}$ & $0.24 \pm 0.02^{\mathrm{a}}$ & $289 \pm 03^{\mathrm{a}}$ & $6.77 \pm 0.23^{\mathrm{b}}$ \\
\hline
\end{tabular}

Pn: Photosynthetic rate $\left(\mu \mathrm{mol} \mathrm{CO} \mathrm{C}^{-2} \mathrm{~s}^{-1}\right)$; Gs: Stomatal conductance $\left(\mathrm{mol} \mathrm{H}_{2} \mathrm{O} \mathrm{m}^{-2} \mathrm{~s}^{-1}\right)$; Ci: Intercellular $\mathrm{CO}_{2}$ concentration $\left(\mu \mathrm{mol} \mathrm{CO} \mathrm{mol}^{-1}\right)$; Tr: Transpiration rate $\left(\mathrm{mmol} \mathrm{H}_{2} \mathrm{O} \mathrm{m}^{-2} \mathrm{~s}^{-1}\right)$. The same letters within each column are not significantly different at the $p<0.05$ level.

\subsection{Leaf Nutrients}

Table 5 shows the leaf macro and micronutrient contents of tea plants at the end of the experiment. Increasing the rates of $\mathrm{CFPH}$ had raised the leaf $\mathrm{N}$ content. Plants that received CFPH $\left(\geq 2 \mathrm{~g} \mathrm{~L}^{-1}\right)$ and FPH showed a significantly higher $\mathrm{N}$ content than the control and other CFPH treatments. Compared with the control treatment, the leaf $\mathrm{N}$ concentration was 18.2 and $15.6 \%$ higher in the CFPH $3 \mathrm{~g} \mathrm{~L}^{-1}$ and FPH treatments. Moreover, the leaf $\mathrm{P}$ 
content showed a similar result, such as $\mathrm{N}$, where significantly higher values were observed in the treatments of $\mathrm{CFPH}\left(\geq 2 \mathrm{~g} \mathrm{~L}^{-1}\right)$ and $\mathrm{FPH}$, highlighting the biostimulant action of animal-origin PH. The leaf P concentration was 19.5 and $16.3 \%$ higher in the CFPH $2 \mathrm{~g} \mathrm{~L}^{-1}$ and FPH treatments, respectively than the control. Significantly higher $\mathrm{Mn}$ and $\mathrm{Cu}$ contents were observed in FPH and higher concentrations of CFPH applied treatments. Chicken feather protein hydrolysate applied at the rate of $3 \mathrm{~g} \mathrm{~L}^{-1}$ increased $\mathrm{Mn}$ by $26 \%$, while the CFPH $4 \mathrm{~g} \mathrm{~L}^{-1}$ dose increased the $\mathrm{Cu}$ content by $21 \%$ compared to the control treatment. Other macro and micronutrients were not significantly affected by the PH application.

Table 5. Effects of animal origin PH on leaf nutrient content.

\begin{tabular}{|c|c|c|c|c|}
\hline & $N\left(g_{k g}^{-1}\right)$ & $P\left(g_{k g}^{-1}\right)$ & $\operatorname{Mn}\left(\mathrm{mg} \mathrm{kg}{ }^{-1}\right)$ & $\mathrm{Cu}\left(\mathrm{mg} \mathrm{kg}{ }^{-1}\right)$ \\
\hline Control & $38.4 \pm 0.4^{b}$ & $2.20 \pm 0.07^{b}$ & $49.7 \pm 0.6^{\mathrm{d}}$ & $6.23 \pm 0.36^{c}$ \\
\hline CFPH $0.5 \mathrm{~g} \mathrm{~L}^{-1}$ & $37.7 \pm 1.8^{b}$ & $2.15 \pm 0.03^{b}$ & $54.0 \pm 1.4^{\mathrm{cd}}$ & $6.31 \pm 0.51 \mathrm{bc}$ \\
\hline CFPH $1 \mathrm{~g} \mathrm{~L}^{-1}$ & $38.9 \pm 1.2^{b}$ & $2.18 \pm 0.07^{b}$ & $59.6 \pm 1.2^{b c}$ & $7.38 \pm 0.54^{a b c}$ \\
\hline CFPH $2 \mathrm{~g} \mathrm{~L}^{-1}$ & $43.7 \pm 1.9^{a}$ & $2.63 \pm 0.19^{a}$ & $64.3 \pm 3.3^{a b}$ & $7.95 \pm 0.53^{a}$ \\
\hline CFPH $3 \mathrm{~g} \mathrm{~L}^{-1}$ & $45.4 \pm 0.7^{\mathrm{a}}$ & $2.53 \pm 0.12^{a}$ & $67.2 \pm 1.3^{\mathrm{a}}$ & $7.56 \pm 0.16^{a b}$ \\
\hline CFPH $4 \mathrm{~g} \mathrm{~L}^{-1}$ & $44.0 \pm 1.1^{\mathrm{a}}$ & $2.63 \pm 0.04^{\mathrm{a}}$ & $66.8 \pm 2.7^{a}$ & $8.36 \pm 0.17^{a}$ \\
\hline FPH $10 \mathrm{~mL} \mathrm{~L}^{-1}$ & $44.4 \pm 0.7^{\mathrm{a}}$ & $2.56 \pm 0.03^{a}$ & $65.5 \pm 1.1^{\mathrm{a}}$ & $7.85 \pm 0.55^{a}$ \\
\hline
\end{tabular}

The same letters within each column are not significantly different at the $p<0.05$ level.

\section{Discussion}

\subsection{Production and Characterization of $\mathrm{CFPH}$}

Protein hydrolysates manufactured from by-products or waste materials generated from agriculture industries have been widely used as plant biostimulants. The chemical properties of $\mathrm{PH}$ are primarily determined by the used production process and protein source [11]. The adopted production process is a crucial factor which determines the amino acid composition and yield of CFPH. The production of CFPH involves physical, chemical, and biological treatments. In chemical treatments, feathers are hydrolyzed by acid or alkali, in which the keratin structure is altered by rupturing the disulphide and peptide bonds [36]. A recent past combination of physical, chemical, and biological methods was adopted to enhance the feather degradation rate and subsequently higher protein recovery [37]. However, detrimental effects of some animal-origin $\mathrm{PH}$ on the plants were reported due to the higher concentration of free amino acids [28]. In this experiment, alkaline hydrolysis was used to produce CFPH since the process is straightforward with many benefits, unlike acid hydrolysis, which requires special equipment to provide the higher temperature and high pressure [38]. The total amino acid content and amino acid composition were more similar to the results obtained by Genç and Atici [32]. The total amino acid obtained in this process was $16.65 \%$, which is higher than the microwave alkali treatment $(6.94 \%)$ by Lee et al. [33] and the hydrothermal treatment (13.6\%) by Nurdiawati et al. [4]. In this study, the produced CFPH contains a higher amount of glutamic acid and proline. Glutamic acid plays a vital role in seed germination, root architecture, pollen germination, and pollen tube growth, while under stress conditions, it takes part in wound response, pathogen resistance, and adaptation to abiotic stress [38]. Proline protects plants from different abiotic stresses and accelerates the recovery of stressed plants [39]. Furthermore, short-chain peptides and certain amino acids, such as phenylalanine, have been reported to increase the production of endogenous auxin by functioning as signaling molecules, resulting in favorable effects on roots and improved vegetative growth $[20,40]$. The presence of small quantities of cysteine $(0.79 \%)$ and threonine $(2.42 \%)$ in CFPH may have resulted due to the aggressive reaction of alkali that ended up in the loss of these amino acids [41]. The peptides and amino acids present in the PH might be directly occupied by plants through the roots and leaf, reaching the target tissues and potentially acting as plant biostimulants [11]. 


\subsection{Shoot and Root Growth}

Animal-origin PH have been widely used in sustainable agriculture for many decades due to their potentiality to enhance plant growth and minimize the impact of environmental stresses. The research explored on CFPH as a potential biostimulant on crop growth has been limited compared to the other animal-derived PH. To the best of our knowledge, the influence of CFPH on the growth of young tea plants has not been previously reported.

In most of the plant experiments, the assessment of plant height, leaf number, and fresh and dry weights can be used as crucial growth indicators reflecting the growth and development of plants. In this experiment, all of the measured parameters related to shoot growth in tea plants were significantly affected by CFPH. Our results are in agreement with the findings of Joardar and Rahman [42], where the treated poultry feather waste enhanced the plant height, leaf number, and plant fresh weight of Ipomoea aquatica. However, contradictory results were reported in mung bean and patchouli plants in response to liquid feather protein hydrolysates, where the plant height and leaf number showed no significant differences with the untreated control, but the plant dry weight was significantly improved [43]. The effect of FPH on the shoot growth of tea was less pronounced than $\mathrm{CFPH}$ since the recommended dosage may not be optimum for the growth of nursery tea.

In this study, CFPH significantly modified the root system by increasing the root length, surface area, and root biomass compared to the untreated control. In another study, the root application of chicken feather hydrolysate produced by feather degrading bacterium significantly increased the root length and root fresh and dry weights in chickpea [31]. The possible mechanism involved in the induced root development could be related to the auxin-like activity of chicken feather hydrolysates [12]. Cristiano et al. [44] reported that root drenching of animal-derived $\mathrm{PH}$ positively influenced the root growth of snapdragon plants compared to the foliar application. The application of $\mathrm{PH}$ for a short period increased the root dry weight of maize plants compared to the untreated plants [22]. This increase in root dry weight may lead to a higher success rate in field planting, which subsequently resulted in better yields [21,45].

The usage of animal origin $\mathrm{PH}$ at higher concentrations may cause plant growth depression in terms of shoot and root growth due to phytotoxicity. Interestingly, the present study revealed that the growth performance of tea plants, which received the highest CFPH dosage $\left(4 \mathrm{~g} \mathrm{~L}^{-1}\right)$ was comparably better than the untreated plants. These results clearly indicate the positive response of tea plants to higher concentrations, as well as the repeated applications of animal-derived $\mathrm{PH}$, which were reported to be toxic to other fruit crops [14,27]. Genç and Atici [32] observed that a low concentration of CFPH $\left(0.75 \mathrm{~g} \mathrm{~L}^{-1}\right)$ significantly enhanced the root length, shoot length, and dry weight of wheat seedlings. Gousterova et al. [46] found that the usage of CFPH at low concentrations exerted a positive effect on seed germination and the growth of ryegrass. Consistent with our findings, previous studies have demonstrated that the beneficial effects of $\mathrm{PH}$ on plants could be seen at low concentrations $[20,47]$.

\subsection{Chlorophyll Content}

In addition to changes in shoot and root growth parameters, the CFPH evaluated in this experiment enhanced the chlorophyll content $(a, b$, and total). Similar results have been reported by Genç and Atici [32] in wheat seedlings in response to the CFPH application, where the $0.75 \mathrm{~g} \mathrm{~L}^{-1}$ dosage was recorded as the highest value. Several authors have found that the animal-derived $\mathrm{PH}$ enhanced the chlorophyll content in beans, corn, soybeans, and tomatoes $[14,48,49]$. The mechanisms behind the enhancement of chlorophyll content by PH are largely unknown [49]. However, the produced CFPH in this study (Table 1) has a higher amount of glutamate $(13.36 \%)$, which is needed for the formation of precursor 5-aminolevulinate, which is involved in the biosynthesis of chlorophyll [50]. 


\subsection{Leaf Gas Exchange}

It is well-known that the $\mathrm{PH}$ improve the photosynthetic rate and ultimately lead to the higher yield with better quality $[11,51]$. Enhancement of physiological parameters, such as the photosynthetic and transpiration rates in tea plants, agrees with the findings by $\mathrm{Xu}$ and Mou [52] for lettuce and Cristiano et al. [44] for potted snapdragon, assuring the higher carbon assimilation. In another study, chicken feather hydrolysate increased the photosynthetic rate in bananas [53]. A high photosynthetic rate of shoots resulted in the higher root activity by supplying an adequate amount of photosynthates to the roots [54]. However, the positive response of CFPH on stomatal conductance and intercellular $\mathrm{CO}_{2}$ concentration was not observed in this experiment.

\subsection{Leaf Nutrients}

Our results suggested that tea plants treated with CFPH and FPH were capable of maintaining a better nutritional status, revealed as higher $\mathrm{N}, \mathrm{P}, \mathrm{Mn}$, and $\mathrm{Cu}$ concentrations in the leaf. No statistical differences were found on the leaf nutrient contents of N, P, Mn, and $\mathrm{Cu}$ among the three dosages $\left(2,3\right.$, and $\left.4 \mathrm{~g} \mathrm{~L}^{-1}\right)$ of $\mathrm{CFPH}$. The plants treated with CFPH $4 \mathrm{~g} \mathrm{~L}^{-1}$ showed higher nutrient contents in leaves despite the reduction in growth parameters. In agreement with our findings, the soil application of animal-derived protein hydrolysates significantly enhanced the leaf $\mathrm{N}$ content by $17 \%$ in potted snapdragon [44]. In a most recent study, root drenching of animal-origin protein hydrolysates improved the leaf $\mathrm{N}$ and $\mathrm{P}$ contents of Petunia plant by 38 and $47 \%$, respectively [55]. The root length and surface area are the key criteria determining the uptake of nutrients and water [56]. In this research, the application of CFPH and FPH positively influenced the root growth of tea, which could facilitate the increased uptake and accumulation of nutrients in plant tissues.

\section{Conclusions}

This study was conducted for the first time to elucidate the positive effects of CFPH on the growth promotion of tea nursery plants. In this experiment, six doses of CFPH $\left(0,0.5,1,2,3\right.$, and $\left.4 \mathrm{~g} \mathrm{~L}^{-1}\right)$ were applied to assess the growth of tea nursery plants. The results clearly showed that the CFPH applied at $2 \mathrm{~g} \mathrm{~L}^{-1}$ significantly enhanced all of the shoot growth and root growth parameters. The chlorophyll content of plants treated with CFPH $1 \mathrm{~g} \mathrm{~L}^{-1}$ showed significantly higher values, whereas the photosynthetic rate was enhanced by the CFPH $3 \mathrm{~g} \mathrm{~L}^{-1}$ treatment. Moreover, the highest dosage of CFPH $\left(4 \mathrm{~g} \mathrm{~L}^{-1}\right)$ showed a positive response on plants' growth and nutrient content compared to the untreated plants. Both of the animal derived $\mathrm{PH}$ applications increased the concentrations of N, P, Mn, and $\mathrm{Cu}$ in the leaves. The FPH positively enhanced the growth of nursery plants, but the exerted positive effect was less pronounced than CFPH. Based on the findings, soil drenching of CFPH at the rate of $2 \mathrm{~g} \mathrm{~L}^{-1}$ could be used as the optimum dose for the successful raising of tea nursery plants. Therefore, the conversion of chicken feathers into CFPH not only improves the growth performance of nursery tea plants, but also eliminates a serious environmental pollution.

Author Contributions: Conceptualization, S.R. and S.K.; formal analysis, S.R.; investigation, S.R. and S.K.; methodology, S.R.; project administration, S.R.; resources, S.K.; supervision, S.K., N.M.J. and M.H.N.; writing—original draft, S.R.; writing—review and editing, S.K., N.M.J. and M.H.N. All authors have read and agreed to the published version of the manuscript.

Funding: This research received no external funding.

Institutional Review Board Statement: Not applicable.

Informed Consent Statement: Not applicable.

Data Availability Statement: The data presented in this study are available on request from the corresponding author. The data are not publicly available. 
Acknowledgments: The authors acknowledge the financial support gratefully from the Ministry of Higher Education Malaysia Grant (FRGS) 5524987 and Sri Lanka Council for the Agricultural Research Policy (SLCARP) for a PhD scholarship.

Conflicts of Interest: The authors declare no conflict of interest.

\section{References}

1. FAO. FAO World Food and Agriculture-Statistical Yearbook 2020; FAO: Rome, Italy, 2020; ISBN 9789251333945.

2. Gessesse, A.; Hatti-Kaul, R.; Gashe, B.A.; Mattiasson, B. Novel alkaline proteases from alkaliphilic bacteria grown on chicken feather. Enzym. Microb. Technol. 2003, 32, 519-524. [CrossRef]

3. Prasanthi, N.; Bhargavi, S.; Machiraju, P.V.S.; Professor, A. Chicken Feather Waste-A Threat to the Environment. Int. J. Innov. Res. Sci. Eng. Technol. 2016, 5, 16759-16764. [CrossRef]

4. Nurdiawati, A.; Nakhshiniev, B.; Zaini, I.N.; Saidov, N.; Takahashi, F.; Yoshikawa, K. Characterization of potential liquid fertilizers obtained by hydrothermal treatment of chicken feather. Environ. Prog. Sustain. Energy 2018, 37, 375-382. [CrossRef]

5. Ben Hamad Bouhamed, S.; Kechaou, N. Kinetic study of sulphuric acid hydrolysis of protein feathers. Bioprocess Biosyst. Eng. 2017, 40, 715-721. [CrossRef] [PubMed]

6. Dudyński, M.; Kwiatkowski, K.; Bajer, K. From feathers to syngas-Technologies and devices. Waste Manag. 2012, 32, 685-691. [CrossRef]

7. Gwyther, C.L.; Williams, A.P.; Golyshin, P.N.; Edwards-Jones, G.; Jones, D.L. The environmental and biosecurity characteristics of livestock carcass disposal methods: A review. Waste Manag. 2011, 31, 767-778. [CrossRef] [PubMed]

8. Baglieri, A.; Cadili, V.; Mozzetti, C.; Gennari, M.; Tabasso, S.; Montoneri, E.; Nardi, S.; Negre, M. Fertilization of bean plants with tomato plants hydrolysates. Effect on biomass production, chlorophyll content and N assimilation. Sci. Hortic. 2014, 176, 194-199. [CrossRef]

9. Schaafsma, G. Safety of protein hydrolysates, fractions thereof and bioactive peptides in human nutrition. Eur. J. Clin. Nutr. 2009, 63, 1161-1168. [CrossRef]

10. Olbrycht, M.; Kołodziej, M.; Bochenek, R.; Przywara, M.; Balawejder, M.; Matłok, N.; Antos, P.; Piątkowski, W.; Antos, D. Mechanism of nutrition activity of a microgranule fertilizer fortified with proteins. BMC Plant Biol. 2020, 20, 126. [CrossRef]

11. Colla, G.; Nardi, S.; Cardarelli, M.; Ertani, A.; Lucini, L.; Canaguier, R.; Rouphael, Y. Protein hydrolysates as biostimulants in horticulture. Sci. Hortic. 2015, 196, 28-38. [CrossRef]

12. Moreno-Hernández, J.M.; Benítez-García, I.; Mazorra-Manzano, M.A.; Ramírez-Suárez, J.C.; Sánchez, E. Strategies for production, characterization and application of protein-based biostimulants in agriculture: A review. Chil. J. Agric. Res. 2020, 80, 274-289. [CrossRef]

13. Morales-Payan, J.P.; Stall, W.M. Papaya (Carica papaya) response to foliar treatments with organic complexes of peptides and amino acids. Proc. Fla. State Hortic. Soc. 2003, 116, 30-32.

14. Cerdán, M.; Sánchez-Sánchez, A.; Oliver, M.; Juárez, M.; Sánchez-Andreu, J.J. Effect of foliar and root applications of amino acids on iron uptake by tomato plants. Acta Hortic. 2009, 830, 481-488. [CrossRef]

15. Kauffman, G.L.; Kneivel, D.P.; Watschke, T.L. Effects of a biostimulant on the heat tolerance associated with photosynthetic capacity, membrane thermostability, and polyphenol production of perennial ryegrass. Crop Sci. 2007, 47, 261-267. [CrossRef]

16. Kunicki, E.; Grabowska, A.; Sękara, A.; Wojciechowska, R. The effect of cultivar type, time of cultivation, and biostimulant treatment on the yield of spinach (Spinacia oleracea L.). Folia Hortic. 2010, 22, 9-13. [CrossRef]

17. Ertani, A.; Pizzeghello, D.; Francioso, O.; Tinti, A.; Nardi, S. Biological activity of vegetal extracts containing phenols on plant metabolism. Molecules 2016, 21, 205. [CrossRef]

18. du Jardin, P. Plant biostimulants: Definition, concept, main categories and regulation. Sci. Hortic. 2015, 196, 3-14. [CrossRef]

19. Nardi, S.; Pizzeghello, D.; Schiavon, M.; Ertani, A. Plant biostimulants: Physiological responses induced by protein hydrolyzedbased products and humic substances in plant metabolism. Sci. Agric. 2016, 73, 18-23. [CrossRef]

20. Colla, G.; Rouphael, Y.; Canaguier, R.; Svecova, E.; Cardarelli, M. Biostimulant action of a plant-derived protein hydrolysate produced through enzymatic hydrolysis. Front. Plant Sci. 2014, 5, 448. [CrossRef] [PubMed]

21. Ertani, A.; Cavani, L.; Pizzeghello, D.; Brandellero, E.; Altissimo, A.; Ciavatta, C.; Nardi, S. Biostimulant activity of two protein hydrolyzates in the growth and nitrogen metabolism of maize seedlings. J. Plant Nutr. Soil Sci. 2009, 172, 237-244. [CrossRef]

22. Halpern, M.; Bar-Tal, A.; Ofek, M.; Minz, D.; Muller, T.; Yermiyahu, U. The Use of Biostimulants for Enhancing Nutrient Uptake. Adv. Agron. 2015, 130, 141-174. [CrossRef]

23. Colla, G.; Hoagland, L.; Ruzzi, M.; Cardarelli, M.; Bonini, P.; Canaguier, R.; Rouphael, Y. Biostimulant action of protein hydrolysates: Unraveling their effects on plant physiology and microbiome. Front. Plant Sci. 2017, 8, 2202. [CrossRef] [PubMed]

24. Polo, J.; Barroso, R.; Ródenas, J.; Azcón-bieto, J.; Cáceres, R.; Marfà, O. Porcine Hemoglobin Hydrolysate as a Biostimulant for Lettuce Plants Subjected to Conditions of Thermal Stress. Horttechnology 2006, 16, 483-487. [CrossRef]

25. Rouphael, Y.; Carillo, P.; Cristofano, F.; Cardarelli, M.; Colla, G. Effects of vegetal- versus animal-derived protein hydrolysate on sweet basil morpho-physiological and metabolic traits. Sci. Hortic. 2021, 284, 110123. [CrossRef]

26. Ruiz, J.M.; Castilla, N.; Romero, L. Nitrogen metabolism in pepper plants applied with different bioregulators. J. Agric. Food Chem. 2000, 48, 2925-2929. [CrossRef] [PubMed] 
27. Lisiecka, J.; Mikołaj Knaflewski, T.S.; Frasszczak, B.; Alina Kałużewicz, W.K. The effect of animal protein hydrolysate on quantity and quality of strawberry daughter plants cv. 'Elsanta'. Acta Sci. Pol. Hortorum Cultus 2011, 10, 31-40.

28. Moe, L.A. Amino acids in the rhizosphere: From plants to microbes. Am. J. Bot. 2013, 100, 1692-1705. [CrossRef]

29. Corte, L.; Dell'Abate, M.T.; Magini, A.; Migliore, M.; Felici, B.; Roscini, L.; Sardella, R.; Tancini, B.; Emiliani, C.; Cardinali, G.; et al. Assessment of safety and efficiency of nitrogen organic fertilizers from animal-based protein hydrolysates-a laboratory multidisciplinary approach. J. Sci. Food Agric. 2014, 94, 235-245. [CrossRef]

30. Nardi, S.; Carletti, P.; Pizzeghello, D.; Muscolo, A. Biological activities of humic substances. In Biophysico-Chemical Processes Involving Natural Nonliving Organic Matter in Environmental Systems; Senesi, N., Xing, B., Huang, P.M., Eds.; Wiley: Hoboken, NJ, USA, 2009; pp. 305-339.

31. Paul, T.; Halder, S.K.; Das, A.; Bera, S.; Maity, C.; Mandal, A.; Das, P.S.; Das Mohapatra, P.K.; Pati, B.R.; Mondal, K.C. Exploitation of chicken feather waste as a plant growth promoting agent using keratinase producing novel isolate Paenibacillus woosongensis TKB2. Biocatal. Agrocult. Biotechnol. 2013, 2, 50-57. [CrossRef]

32. Genc, E.; Atici, Ö. Chicken feather protein hydrolysate as a biostimulant improves the growth of wheat seedlings by affecting biochemical and physiological parameters. Turk. J. Bot. 2019, 43, 67-79. [CrossRef]

33. Taskin, M.; Ozkan, B.; Atici, O.; Aydogan, M.N. Utilization of chicken feather hydrolysate as a novel fermentation substrate for production of exopolysaccharide and mycelial biomass from edible mushroom Morchella esculenta. Int. J. Food Sci. Nutr. 2012, 63, 597-602. [CrossRef] [PubMed]

34. Coombs, J.; Hind, G.; Leegood, R.C.; Tieszen, L.L.; Vonshak, A. Analytical Techniques. In Techniques in Bioproductivity and Photosynthesis, 2nd ed.; Pergamon Press: Oxford, UK, 1987.

35. Bremner, J. Methods of Soil Analysis: Part 2 Chemical and Microbiological Properties; Wiley: Hoboken, NJ, USA, 1965; Volume 9, pp. 1149-1178.

36. Lee, Y.S.; Phang, L.Y.; Ahmad, S.A.; Ooi, P.T. Microwave-Alkali Treatment of Chicken Feathers for Protein Hydrolysate Production. Waste Biomass Valorization 2016, 7, 1147-1157. [CrossRef]

37. Cheong, C.W.; Lee, Y.S.; Ahmad, S.A.; Ooi, P.T.; Phang, L.Y. Chicken feather valorization by thermal alkaline pretreatment followed by enzymatic hydrolysis for protein-rich hydrolysate production. Waste Manag. 2018, 79, 658-666. [CrossRef] [PubMed]

38. Qiu, X.M.; Sun, Y.Y.; Ye, X.Y.; Li, Z.G. Signaling Role of Glutamate in Plants. Front. Plant Sci. 2020, 10, 1743. [CrossRef] [PubMed]

39. Hayat, S.; Hayat, Q.; Alyemeni, M.N.; Wani, A.S.; Pichtel, J.; Ahmad, A. Role of proline under changing environments: A review. Plant Signal. Behav. 2012, 7, 1456-1466. [CrossRef] [PubMed]

40. Del Buono, D. Can biostimulants be used to mitigate the effect of anthropogenic climate change on agriculture? It is time to respond. Sci. Total Environ. 2021, 751, 141763. [CrossRef] [PubMed]

41. Bellagamba, F.; Caprino, F.; Mentasti, T.; Vasconi, M.; Moretti, V.M. The impact of processing on amino acid racemization and protein quality in processed animal proteins of poultry origin. Ital. J. Anim. Sci. 2015, 14, 3770. [CrossRef]

42. Joardar, J.C.; Rahman, M.M. Poultry feather waste management and effects on plant growth. Int. J. Recycl. Org. Waste Agric. 2018, 7, 183-188. [CrossRef]

43. Nurdiawati, A.; Suherman, C.; Maxiselly, Y.; Akbar, M.A.; Purwoko, B.A.; Prawisudha, P.; Yoshikawa, K. Liquid feather protein hydrolysate as a potential fertilizer to increase growth and yield of patchouli (Pogostemon cablin Benth) and mung bean (Vigna radiata). Int. J. Recycl. Org. Waste Agric. 2019, 8, 221-232. [CrossRef]

44. Cristiano, G.; Pallozzi, E.; Conversa, G.; Tufarelli, V.; De Lucia, B. Effects of an animal-derived biostimulant on the growth and physiological parameters of potted snapdragon (Antirrhinummajus L.). Front. Plant Sci. 2018, 9, 861. [CrossRef]

45. Zhang, X.; Ervin, E.H.; Schmidt, R.E. Physiological effects of liquid applications of a seaweed extract and a humic acid on creeping bentgrass. J. Am. Soc. Hortic. Sci. 2003, 128, 492-496. [CrossRef]

46. Gousterova, A.; Nustorova, M.; Paskaleva, D.; Naydenov, M.; Neshev, G.; Vasileva-Tonkova, E. Assessment of feather hydrolysate from thermophilic actinomycetes for soil amendment and biological control application. Int. J. Environ. Res. 2011, 5, 1065-1070. [CrossRef]

47. Ertani, A.; Pizzeghello, D.; Francioso, O.; Sambo, P.; Sanchez-Cortes, S.; Nardi, S. Capsicum chinensis L. growth and nutraceutical properties are enhanced by biostimulants in a long-term period: Chemical and metabolomic approaches. Front. Plant Sci. 2014, 5, 375. [CrossRef] [PubMed]

48. Kurbanoglu, E.B.; Atici, O.; Algur, O.F. Effect of ram horn hydrolyzate on the growth of bean (Phaseolus vulgaris cv. aziziye-94). Biol. Agric. Hortic. 2004, 22, 121-131. [CrossRef]

49. Horii, A.; McCue, P.; Shetty, K. Seed vigour studies in corn, soybean and tomato in response to fish protein hydrolysates and consequences on phenolic-linked responses. Bioresour. Technol. 2007, 98, 2170-2177. [CrossRef]

50. Gough, S.P.; Westergren, T.; Hansson, M. Chlorophyll biosynthesis in higher plants. Regulatory aspects of 5-aminolevulinate formation. J. Plant Biol. 2003, 46, 135-160. [CrossRef]

51. Rouphael, Y.; Colla, G.; Giordano, M.; El-Nakhel, C.; Kyriacou, M.C.; De Pascale, S. Foliar applications of a legume-derived protein hydrolysate elicit dose-dependent increases of growth, leaf mineral composition, yield and fruit quality in two greenhouse tomato cultivars. Sci. Hortic. 2017, 226, 353-360. [CrossRef]

52. Xu, C.; Mou, B. Drench application of fish-derived protein hydrolysates affects lettuce growth, chlorophyll content, and gas exchange. Horttechnology 2017, 27, 539-543. [CrossRef] 
53. Gurav, R.G.; Jadhav, J.P. A novel source of biofertilizer from feather biomass for banana cultivation. Environ. Sci. Pollut. Res. 2013, 20, 4532-4539. [CrossRef]

54. Yang, C.; Yang, L.; Yang, Y.; Ouyang, Z. Rice root growth and nutrient uptake as influenced by organic manure in continuously and alternately flooded paddy soils. Agric. Water Manag. 2004, 70, 67-81. [CrossRef]

55. Cristiano, G.; De Lucia, B. Petunia Performance under Application of Animal-Based Protein Hydrolysates: Effects on Visual Quality, Biomass, Nutrient Content, Root Morphology, and Gas Exchange. Front. Plant Sci. 2021, 12, 608. [CrossRef] [PubMed]

56. Ryser, P. The mysterious root length. Plant Soil 2006, 286, 1-6. [CrossRef] 